\title{
Political Development Concept by Looking Briefly at the Iran's Mohammad Reza Pahlavi Rule
}

\author{
Maryam Karimi \\ Faculty of Human Ecology, University Putra Malaysia, Kuala Lumpur, Malaysia \\ Email: Maryam4791@gmail.com
}

Assoc.Prof.Dr.Sarjit Singh Darshan Singh (Corresponding author)

Faculty of Human Ecology, University Putra Malaysia, Kuala Lumpur, Malaysia

Email: sarjit@putra.upm.edu.my

Accepted: November 05, 2014

Doi:10.5296/ jpag.v4i4.6627 URL: http://dx.doi.org/10.5296/ jpag.v4i4.6627

\begin{abstract}
Concept of political development such as other concepts of political science has a lack of consensus among researchers and scholars. This article is going to review the concept of political development. It begins with an overview on definitions of political development. Presumably, it presents different aspects and characteristics of political development. This article establishes Iran's efforts towards political development during Mohammad Reza Pahlavi Rule. Moreover, this article concludes that process of political development in Iran was affected by two main theories of political development by some western and Iranian political thinker's definition on this concept.
\end{abstract}

Keywords: Political development; Iran; Mohammad Reza Pahlavi 


\section{Introduction}

Concept of political development is being used much more meaningful in modern times in the expression of development in so many nations of Asia, South America and Africa in twentieth century. In this concept, the modernization, growth and development are mostly important and undeniable. Political development, as a usable concept has been involved to a huge number of political, economic and sociological studies upon this concept. Lucian W. Pye's study is particularly important, on this concept that he states out the political development is "adjustment between old patterns of life and new demands".

The idea of political development has considered as a necessary requirement to achieve democracy and self-reliance in political history of twentieth century. Nowadays, political development is really universal concept that is placed in most of nations in the world. By the way, it is a questionable term which does not have sustainable meaning, e.g. Almond used it as mobilization of power; Lerner described political development as one aspects of multi-dimensional social change process; LaPalombara called this as a building of democracy (Almond, 1960; Lerner, 1958; Lapalombara, 1963).

Many challenges emerged during investigation on this concept for researcher to understand the issue of political development. Firstly, there are different definitions and views used by political thinkers, sociologists and economists, because political development has been multi-dimensional concept. Variety in scholar's views have been had fundamental evolvement in political development process. The various politicians have expressed divergent views about the necessity, non-necessity and advantages of this concept. But the political thinkers contributed to the evolution of this concept as the way they were interested in to reach the political development aims. Another problem comes out when the Western concepts uses in Non-Western societies particularly in the Middle East countries. Religious countries such as Iran, has not good conditions to use Western political thoughts. As seen the political development had not taken place properly throughout the reign of Mohammad Reza Pahlavi.

The above mentioned problems need to check out the characteristics of political development and find it out, how the most massive movements in political development have been started in twentieth century, particularly after 1953s. Thinking is whether United Nations declarations and Charters and its agencies could have been succeeded to progress of political development process.

Researcher mentioned the perspectives of political development, all display the different main aspects of this concept. The article pays attention to universality of political development started after frustrations following World War One. Moreover, traditional people were finding a new place under the new themes of political development. International legitimacy to human rights and sharing interests between East and West also took place under the international conferences. In the next part, it presents some of the most important theories of political development that one focuses on different characteristics of both modern policy and traditional policy, and the second one as a modern force. Also, the article mentions Iran's political development evolution in Mohammad Reza Pahlavi rule indicating how this concept has been work on Iran's society as well.

\section{Concept and definitions of Political Development}

Political development is a vast area of study in politics and involves different views. Accordingly, there is diversity in definitions of political development and its relation to social, economic and culture of any society. Most definitions have emphasized the necessary features of political development. This part will give some definitions of political development, and later discusses the origins of Iranian political development after 1953.Political development, in general, is defined as the adjustment between old patterns of life and new demands, in relation to political aspects. As, Lucian W.Pye (1965) mentions, "Political development is a basic concept supporting the gradual diffusion throughout all societies of what we might call a world culture." According to him, the first step to reach 
political development is the development of a national state. He points out, political development can be in the whole population, at government level and in the organization of political system as well (Pye 1965).

As Almond (1960) points out, political development is mobilization of power. According to Weber and after him, La Palombara (1963), political development is administrative development and legal development in which bureaucracy is the main point of political development. Lerner (1958) describes political development as one aspect of multi-dimensional social change process. Defining political development, La Palombara also writes that political development is the building of democracy by promoting democratic values among the people (Almond and Coleman 1960, La Palombara 1963).

As we can see, Pye (1966) mentions other views about political development. For example, the economists point out that political prerequisites as well as social ones play a crucial role in facilitating increase in per capita income. Definitely, they assume political development as facilitating economic growth and industrial development that is necessary for realizing higher economic performance. Others emphasized political development as general performance of the entire system that created the integrated society. Understandably, the most common viewpoint that one may take into consideration to understand political development's definition is that political development consists of a large number of changes in different layers of the society, taking into account, state performance, people's welfare, activities of the elites, socio-economics and progresssive political culture tendencies. In this regard, with respect to governmental performance, political development includes an increasing of capacity of the political system to manage public affairs, control conflicts, and cope with popular demands (Pye 1966).

Definitely, Pye (1966) has emphasized that political development strikes at the roots of people's beliefs and sentiments about politics. In the light of these different views, political development had not taken place properly throughout the reign of Mohammad Reza Pahlavi. Thus in Iran, one begins to appreciate the long gradual process of development in institutional and attitudinal preparation for modernization in the socio-economic level. Iran's king modernized at the socio-economic level but in the political development process, he did not permit the formation of pressure groups, failed to create cordial ties between the people (especially lower classes) and regime, and did not open the political arena for different social groups and broaden the social base of the monarchy in Iran that was very necessary for political progress simultaneously with Iran's modernization (Abrahamian 1982) .

Finally, the political development goals that meant broadening the political participation and political competition of social and political groups in political life, did not materialize in Iran. One key result of this is that there was no orderly change and progress of development plans of Iran's king at the three levels of politics, social and economics. Critically, with regards to definitions stated earlier, political development remained lifeless and weak in Iran under the rule of Mohammad Reza Pahlavi.

\section{Characteristics of Political Development}

The concept of political development involves a set of characteristics and these characteristics lie behind the various definitions of political development which seem to be most widely held and most fundamental in the general consideration about problems of development. Equality is noted as a first characteristic for political development. In many views, political development does involve mass participation and popular involvement in political activities. For participation either in democratic or totalitarian form of government, these must be pretenses of popular rule for subjects so that they should become active citizens (Pye, 1966).

In fact, equality means that laws should have a nature of universality that must be applicable to all classes of people and it is not only for personal purposes of special minority groups. In fact it means all people whether rich or poor, strong or weak, should submit to the same dictates of law. Moreover, equality should be on the basis of standards of performance to gain 
political office and officeholders should have met some test of competence before gaining office under political systems.

Corry (1959) says: "The ideal of equality has insisted that men are politically equal, that all citizens are equally entitled to take part in political life to run for and hold office. It has insisted that individuals shall be equal before the law, that when the general law confers rights or imposes duties, these rights and duties shall extend to all; or conversely that the law shall not confer special privileges on particular individuals or groups." Basically, equality stands for four principles: (1) all persons are provided with adequate opportunities for the development of their characters. (2) No special group or class is given special privilege which is defined to others. (3) Rights are equally distributed among all people and groups. (4) All should have equal opportunities leading to authority (Corry 1959, Gokhale 2006).

A second major characteristic in political development deals with the capacity of a political system. Capacity is related to outputs of a political system and political systems can have an effect on society and economy. Also, capacity is associated with government and its performance and any conditions that can affect government performance. Thus firstly, capacity entails the scope of political and governmental performance, secondly, capacity means effectiveness in the scope of public policy execution, and thirdly, capacity is related to rationality in administration. It does mean that government's actions tempered with more deliberations and justification will make it more likely for government to achieve the ends and means (Pye 1966).

In Lucian Pye's viewpoint of characteristics of political development, the third theme in political development is differentiation. Differentiation is diffusion of specialization. In the developing political system, different agencies and offices tend to have their distinct and limited functions. So differentiation is specialization based on a final sense of integration. Political systems with differentiation can increase functional specificity of the various political roles.

Moreover, differentiation involves the integration of complete structures and process and as a result it is not isolated to the different parts of the political system. All the above mentioned characteristics of political development may fit or may be not easily fit together. But, historically, there has been a tussle between the demands for equality, the requirements for capacity, and the process of differentiation. Pressure for equality may upset the political system and differentiation may reduce equality. Characteristics of equality are related to political culture and characteristics of capacity are connected with government performance (Pye 1966).

Different patterns of development in different societies have dealt with different dimensions of development syndrome, so the development is not unilateral. According to Pye, "This suggests that in the last analysis the problems of political development revolve around the relationship between the political cultures, the authoritative structures and the general political process".

\section{Political Development After 1945}

The most massive movement in political development has been in the twentieth century. The values of political development had started in theory, at first in United States and step by step went through the practical stages until it took root. The beginning of 1945 was a start for a special outlook as practical attempts were made in Iran for promoting political development but there occurred changes more of a socio-economic nature.

Gradually, there was created a world in which political development and its values were paid much more attention by governments in international circles, especially western countries. President Roosevelt of the United States, in a message to Congress in January 1941, had spelt out four forms of freedoms as being of universal importance. These were: (a) Freedom of speech and expression (b) Freedom to worship (c) Freedom from want (d) Freedom from fear. For the United Nations that was set up in 1945, that was a good message too. Actually it 
was the beginning of political progress in the world. On 14 August 1941, Roosevelt and Churchill - Britain's Prime Minister - issued a famous Atlantic Charter which spoke about peace, meaning safety of all nations within their boundaries. This charter was a step forward for political development in the whole world. And all of these efforts were endorsed by 26 countries that were then Allies, on January 1942 in what came to be known as the United Nations Declaration that was signed in Washington and finally the United Nations was established on October 24, 1945.

This was a good development for all sovereign, peace-loving countries of the world. Iran also has been one of the founder-members of the United Nations Charter and many of its specialized agencies. The Yalta Summit attended by Churchill, Roosevelt and Stalin which was held in USA resolved issues such as voting procedure in the Security Council, and Soviet demand for membership of all its sixteen unions' republics, beside itself. After this summit, the charter draft of United Nations was finally adopted at a Conference in San Francisco. Iran also was invited to send a delegation to the San Francisco Conference (April-June 1945) (Gokhale 2006).

Iran signed the Charter deliberately and this Charter was a step forward to political progress in the world, especially in Iran after 1945. The issue of political development has been reinforced as one of the major issues in the foreign policy of the United States and members of the European Union. This has been seen as the second wave of democracy in the world as Samuel Huntington said in his book The Third Wave of Democratization. Political development is still increasingly under assessment and investigation in the world of politics and it has changed to become a major issue while governments are going on with their struggles against freedom and democracy and political progress. A large number of conventions and international treaties gave credit to political development. At the present time, there are not only different international treaties and conferences that talk about the values and importance of the political development but also a great number of national institutions and organizations are educating people around the world through their annual meetings as well.

\section{Universality of Political Development}

There are four important perspectives of political development: stability and gradual change of political development; political participation and mass mobilization of political development; nation-building; and sense of national dignity in international affairs. These four perspectives all display different main aspects of political development. In fact, the field of political development was new in the 1960s (Hagopian 2000).

This section will describe the impact of these perspectives on political development and determine how Mohammad Reza Pahlavi in one hand joined the United Nations as one of the first signatory members and accepted all of the conventions relevant to social and political development. On the other hand, it emphasizes the importance of political progress for the Pahlavi regime to achieve internal and external aims.

Discussion about universality of political development started after frustrations following World War One. Rustow (1970), In developing regions like Middle Eastern countries, the version of political development is different. Unfortunately, at that time, some new states were likely to slip from democratic regime to autocratic ones such as Iran during Reza Pahlavi's rule (1926-1941). But when World War II ended with breaking up of great empires, suddenly there were more new states created in the world. The theme of democracy and liberal aspirations accompanied the birth of the new nations. The United Nations Charter that was written in 1945 was the guide for the nations and states about their human, political and socio-economic rights (Rustow 1970).

As Pye (1966) mentions, political development has proved to be a difficult, but existing process. In the shadow of the political development and the UNICCPR -United Nations International Convention Civil and Political Rights- the new generation had been captivated by the prospect of traditional people finding a new place under the new themes of political 


\section{MInstitute Mach $^{m}$}

Journal of Public Administration and Governance

ISSN 2161-7104

2014, Vol. 4, No. 4

development. La Palombara (1963) explains the rapid change and frequently increasing progress in the world as disappearing colonialism, revolution in communications and technology, international technical assistance and raised economic progress, social and political stability. Also, political maps of the world changed and increased number of nation-states, debaters and voters of United Nations dramatically announced the presence of new nations. The shifting balance of power and as a whole, conditions of economic distress, physical violence, particularly, political maneuvering somehow seem to have had direct bearings on peace in the entire globe. Pye points out the political development may be found in three levels: in the whole population, on the government level and in the organization of political system. As a matter of fact, on the basis of Pye's view, political development was approved in Iran's constitutional movement in the early twentieth century.

Creation of new states, and so many changes in different countries such as the coalition government in Laos, agricultural reform in China, land reform In Iran, India's five-year plan, industrial development in Ghana, Nigeria improving its literacy rate, military coups in Turkey, Korea and so on, are all symptoms of development, and most of them are consequences of nation-states' awareness of freedom and progress in multi-dimensional stage of development, particularly in political rights. Certainly this awareness has occurred earlier in the eighteenth century; the events of United States' "Declaration of Independence" (1776) and "France Declaration of the Rights of Man" (1789) gave way to a new concept of government for human beings and established the rights of individuals.

Subsequently, the process of political development was politically completed in the Bolshevik Revolution in Russia that was one of the most significant political innovations of the twentieth century. Political development continued in the twentieth century as Samuel Huntington has mentioned in his book titled 'The Third Wave' which was about democratization waves that are part of a political development process which happened in the twentieth century. In the following years Conference Security and Cooperation in Europe (CSCE), that was about international legitimacy to human rights and freedom and sharing interests between East and West, also took place. Also the Helsinki Final Act (1975) set forth as one of its ten principles, "respect for human rights and fundamental freedom, including the freedom of thought, conscience, religion or belief." It also created a conference on human dimension (1989) which endorsed the rule of law, democracy, political pluralism, the right to form political parties and free and fair election. Obviously, process of political development leads to a growing demand for political participation, and political change that determined the degree of political stability in political process.

Universality and comprehensiveness of political development process is a commendable goal that is exposed through the international language of politics and in the forms of different political and legal treaties and conventions so that protecting the requirements of political development - the inter-related world, stability, participation and competition - from governments that violate political development becomes possible. The universality of political development puts forward the viewpoints and standards of the issue of political development characteristics - equality, capacity and differentiation (Pye, 1966) - according to which the observation of political development changes to a priority and a life with political awareness, autonomy and human freedom and rights dignity becomes possible. Thus, generally the universality of political development presupposes the observation of political progress as the crucial base for international political development that globally pays attention to the rights of development in political systems. Basically movements towards democracy, national integration, political participation, modernization and political competition are emphasizing the universality of political development values.

\section{Nation-building}

The world politics in the twentieth century has been merged and engulfed by terms related to a new view of nation-building - the developing areas, economic development, political progress, charismatic leaders, neutralism, the revolution of rising expectations, foreign aid, the alliance for progress, modernization, the emerging nations, intellectual elite, peasant 
masses, international lending agencies and many other political programs. In many countries, the domestic development was going to be facilitated by its strong government. As hemant Shah (2003) says about lerner ideas that the urbanization and litracy caused to growth of mass media which all are related to nation-building. New professions of the technical advisors and development administrators have come into being. America has had the important role in helping others to achieve their ambitions of development (Pye 1965, Hemant 2003).

Historically, man's potency was looking forward to advancement and there was much nobility in the view of man's potentialities. Of course, there has been cynicism and feeling of futility became of the easy optimism in the first years of the era of nation building but it is reality that the purposeful programs and new orders in political development cannot come into being overnight. Definitely, there have been problems in nation-building process and political development that remain still. But the people, particularly, new nations in Asia and Africa must find new arrangements to give them dignity. So, there must be more learning about the nature of political development to avoid cynicism, for effective purposeful change (Zonis 1968).

We now seek to understand how the concept of nation-state was gradually diffused especially from Europe to the entire world. For the past three centuries, western contacts with the rest of the world have been unstoppable efforts of the European state system to transform all societies into replicas of the nation-state. As we might assume, every person feels to belong to some polity, and all polities to behave as proper states within the family of the nations (Pye 1966).

If a political system is to be considered as developed, there must be attention to all development criteria (Sedehi and Tabriztchi, 1974). So, it recognizes the demands of both the nation-state system and the world culture which underlie the nation-building process in the new states. But in the process of nation-building, the diffusion of the world culture can destroy the structure of traditional societies, but it cannot reconstitute a modernized society easily. However, to acculturate for creating all forms of organizations, it needs to support the social, economic and political activities associated with modern life and it improves the abilities of the people to maintain modern organizations (Pye, 1964). In fact, the nation-building process developed by Gabriel Almond was unilinear, teleological and ethnocentric in Pye's view of Gabriel Almond approach in political development (Pye 1964, Sedehi and Tabrizchi 1974, Burnel 2005).

Pye (1966), quoted: "Development entails the translation of diffused and unorganized sentiments of nationalism into a spirit of citizenship, and equally the creation of state institutions that can translate into policy and programs for the aspirations of nationalism and citizenship. In brief, political development is nation-building." In the same sense, in fact, in Iran's Pahlavi period, gradual diffusion in the society of Iran happened and sentiment of nationalism had been found but it was not as robust as state functions and performance. Yet, it should not be forgotten that the administrative arts as a prerequisite to nation-building had not been fulfi

\section{Theories of Modernization and Nationalism}

\subsection{Modernization}

The impact of modernization on political development is really varied. Many authors have defined modernization in numerous ways. The modernization definition focuses on the differences between what are assumed to be the distinguished characteristics of both modern policy and traditional policy as well.

Modernization is a multilateral process that involves changes in all areas of human ideas and activity. As Lerner (1958) said, "a process with some distinctive quality of its own, which would explain why modernity is felt as a consistent whole among people who live by its rules." Lerner also said the aspects of modernization such as industrialization, secularization, 
democratization, education, urbanization, and media participation are related and they are associated either as independent factors or may be historically linked (Lerner 1958) .

Firstly, as an aspect of modernization, is social mobilization, which involves changes in the aspiration of individuals and societies, as Karl W.Deutch noted in 1961. Secondly, economic development involves growth of total economic activities and output of a society and changes in people's capabilities. But modernization needs both of them and in the world of modernization, crucially political modernization aspects are defined in numerous ways. In this sense, political modernization has three headings. First, political modernization involves the rationalization of authority. It means replacement of traditional authorities to national political authorities. Second, political modernization involves the differentiation of new political functions and progress structure to perform those functions. The third is increasing participation in politics by different groups in society. So, "rationalized authority, differentiated structure and mass participation thus distinguish modern politics from antecedent politics" (Deutch 1961, Hungtington 1968).

The government of Iran moved forward with policies of modernization and development but most reports confirm that in some parts of Iran, there were classes and groups which were hesitant about the virtues of modernization. Anyway, modernization in Iran in Mohammad Reza Pahlavi's reign had not been succeeding due to certain reasons. Some believed that this government was inefficient; some held that it was the lack of administrative skills; others believe that it was the degeneration of Iranian culture, thinking that the government must be fully responsible for the country's modernization and to solve the problems occurring due to it. Unfortunately, rationalization, modernization and development had brought military dictatorship and made the political environment more repressive in Iran (Binder 1962).

During the process of modernization, in the first part, it must be process of learning new skills and the acceptance of new ideas about the nature of the world and of human relations as well. Also, in another part of this process, it entails the acceptance of new values and the changing of preferences. Furthermore, in this way, there is fundamental change in motivations and direction in which human energy is directed properly. So, the difficulties which hinder easy political development are obviously less related to uncertainty over rational choices than hesitations over motivations. In recent years, there have been questions of whether breaking of traditional order can create complex hesitations that may affect the motivations in individuals. Moreover, there is the question of how modernization can build up the crucial sets of motivations for people who perform as members of the modern world.

Some politicians have emphasized the view that political development is synonymous with political modernization ( Lipset,1959; Coleman,1960; Deutch,1961). They have defined political development as the crucial character of political modernization. These are characteristics of modern western countries. According to Pye (1966), this view fails to distinguish between western and what was modern; political development and modernization (Pye, 1966). In the next section, nationalism is explained more as a main theory of political development in Iran (Lipset 1959, Deutch 1961).

\subsection{Nationalism}

As a main theory of this study, nationalism had played the crucial role to political development process in Iran, pre and post 1953. The actual feeling of nationalism manifests only when some kind of homogeneity is created in the state as a result of a plurality of factors. Nationalism is a feeling of oneness, togetherness and common consciousness based on political, historical, religious, linguistic, racial, cultural and other important factors that can influence society and government. People can constitute a nation by nationalism in an independent state. The sentiments created by nationalism should be strong enough to raise collective political consciousness among people to reach political aims. Harold Laski in his book, 'A Grammar of Politics' (1967), says nationalism 'Implies the sense of a special unity, which marks off those who share in it from the rest of mankind. That unity is the outcome of a common history of victory won and traditions created by corporate effort" (Laski 1967). 
Nationalism is a modern force that was absent in ancient and medieval times. Nationalism became a great force in Europe in the nineteenth century and went hand in hand with democracy and rapidly gained ground in Afro-Asian countries in the twentieth century. In all countries, common political aspiration is one of the factors that is quite essential for the development of nationalism. Iranian nationalism grew vigorously and became a mighty force during the oil nationalization event under the leadership of Dr. Mosaddiq in 1951. Although, Iranian nationalists were not unified enough as a nation, or too corrupt, the Shah was too interested in preserving traditional institutions to support his monarchy (Pye 1964).

A nation might be defined as a human group, occupying a country with definite boundaries, sharing common traditions, aspirations that are bound by common sentiments and it should possess goals which bind the community with a unifying thread. The sentiments of nationalism are a common feeling that binds a group into a similar whole. Actually, in the development of nationalism, the elites have to play the important role, because nationalism is a vital force for modern times which emerged in the nineteenth century and more impressively, in the twentieth century. Laski in his book ,A Grammer of Politics, says: 'Broadly speaking, in fact the idea of nationality is essentially spiritual in character'. He believes growing up with a sense of kinship binds men in oneness (Laski 1967).

Iranian nationalism emerged as a protest movement to the expansion of western capitalism and its political and cultural consequences created the economic and religious reactions. Ulama combined with bazaar (traders) in this movement against western penetration. But, it was in the early nationalism period in the second half of the nineteenth century that led towards the form of nationalism expressed by Islam predominantly. After that, in the twentieth century, the Pahlavis adopted integral nationalism which was itself a western idea. Another group that was manifested in the political arrangement of the social formation was modern intelligentsia, which played an instrumental part in the 1979 revolution (Bashiriyeh 1984).

In Pye's viewpoint in his book (1964), 'Communications and Political Development', Iran was low in affiliation and was high in power in 1950, which is a sign of totalitarian regime. The findings of Pye apparently mean that certain elites in Iran, particularly the governing elites, wanted to have their own power and they did not care enough about other people's affiliations to avoid treating them violently if need be. In this sense, "at least among, significant elites in the country, which supports violence as a solution to difficulties". political development will have to be understood, not only in terms of power relationships between different sub-groups in a society, but also in terms of the motivational characteristics of theses sub-groups and the presence, or absence, of dictatorial motivational pattern (Pye 1964).

As a symbol of legitimacy, nationalism is in the lower dispute than other symbols, in Iran. There were five coexisting legitimizing formula, that is: monarchy, aristocracy, theocracy, nationalism and constitutionalism. The monarchy was attacked, limited, transformed, and renewed, during the first half of the twentieth century in Iran. Binder (1962) The aristocracy had accepted new elements and titles had been dropped. Many religious authorities had been deprived of much influence, so, they rejected the regime and its modernization plan, both within and without. In the formula, it was nationalism that was important in the political development process of Iran. From the beginning of the twentieth century, there had been extreme nationalism of Reza Shah Pahlavi which had been replaced by the "negative nationalism" of Dr Mosaddiq and then the "positive nationalism" of Mohammad Reza Pahlavi in Mohammad Reza Pahlavi view. Furthermore, nationalism remained a central issue of Iranian politics and ideology and opposed imperialism. It had to be anti-American, anti-Soviet or anti-British. The last element was Iran's constitution that in spite of serious amendment still remained in effect (Binder 1962).

As Binder noted in his book, 'Iran', "There are some special varieties of nationalization which emerged during the Mosaddiq period and which still lie beneath, but close to the surface, of Iranian politics." These varieties may be leftist nationalism that was best seen in the Tudeh 
party (party of the masses) that was meant for the general public rather than for their own members. The nationalist slogans of Tudeh emphasized on workers' and peasants' rights. The second variety was nationalist of the right that was termed as Pan-Iranist. This group has court support. They targeted the average young intellectuals. The third was the 'nationalists of the middle' , a name used by the Iranian national resistance movement by which they are referred to in a subtitle of the publication "In the Way of Mosaddiq". They were from different parties but their slogan was anti-American (Binder 1962).

Without doubt, Mohammad Mosaddiq was the country's most seasoned politician. He became a symbol of great nationalism and a national hero by playing skillfully on Iranian hatred of foreign intervention, and this was symbolized by his nationalization of the oil industry. He was as much concerned to humiliate the Pahlavis especially in the case of oil nationalization and Mohammad Reza Pahlavi knew of that, and he says in his book, 'Mission of my Country' (1960) “ Mosaddiq had relatives of Qajar blood ... his policy was clearly to do everything possible to discredit the Pahlavi dynasty...". In the case of nationalization of oil (George Lenczowski, 1972; Bashiriyeh, 2001; Abrahamian, 1982) pointed out details of British and American involvement in the domestic policy of Iran indirectly. Actually in the late 1940s both the Shah and the 'National Front' under Mosaddiq's leadership struggled for the nationalist mantle. In this competition, Huntington (1968) quoted, "the Shah not only opposed Russian designs on his country but also to assent to Iranian national interest against the Anglo-Iranian oil company and to develop his doctrine of 'Positive Nationalism' against the 'Negative Nationalism' of Mosaddiq" (Lenczowski 1972, Abrahamian 1982, Bashiriyeh 2001, Abrahamian 2008).

Finally, nationalists, blamed the foreigners too often and it became an easy way to avoid facing issues and created domestic problems, particular in the process of political development (Chahabi 1990). Nationalism believes In a coherent and consistent set of values that empower the ability of people and states to follow their own interest in unity and the framework of acceptable collective rules that facilitate cooperative and developed the people and the state in social, and particularly, political arena.

\section{Conclusion}

This article presents concept of political development that shows different views and aspects of this concept by political tinkers, sociologists and economists who had their own view upon this significant concept of political science. Different usable on this concept between the West and East societies had been more challengeable in twentieth century. Even though, there was not unique understanding on this concept. This article establishes more challenges faced by Mohammad Reza Pahlavi in political development, the years under his rule in Iran. Based on political development factors and characteristics on development plan, particularly in Iran, shifting ideas of national government to traditional authorization approach and modernize Iran, is provided the political development fluctuations during Mohammad Reza Pahlavi reign. In fact, in the process of political development assessment, the analysis of capabilities enable researchers and scholars to explain the cycle of long-range or short-range change in response to any kind of environmental process. So, this capabilities show the capacity of political system in any society and how the political system will work under their pressure. The challenge in the most views of political development is intention to pave the path of democracy as one of the factors of political development. But, in fact, this is very different usable way between the West and East societies. In theories of political development, the scholars try to define variety of viewpoints. A prominent point in this review is the failure of Mohammad Reza Pahlavi to managing his development plan upon Iran. The legitimacy confusion, manifested in the inequality of power relationships, problem in the exploration of new political techniques appeared in the first period of Iran's political development. 
References

Abrahamian, E. (1982). Iran Between Two Revolutions. US, Princeton University Press.

Abrahamian, E. (2008). A History of Modern Iran. U.K, Cambridge University Press.

Almond, G. A. and J. S. Coleman (1960). The Politics of the Developing Areas. U.K, Princeton University Press.

Bashiriyeh, H. (1984). The State and Revolution in Iran,1962-1982. U.S, ST.Martin Press, Inc.

Bashiriyeh, H. (2001). Obstacles to Political Development in Iran. Iran, Gam-e no.

Binder, L. (1962). Iran: Political Development in a Changing Socity. U.S, University of California press.

Burnel, P. (2005). Politics in the Developing World. U.K, Oxford University Press.

Chahabi, H. E. (1990). Iranian Politics and Religious Modernism. UK, I.B.Tauris \& Co.Ltd.

Corry, J. A. (1959). Democratic Government and Politics. Canada, University of Torento Press.

Deutch, K. W. (1961). "Social Mobilization and Political Development." The American Political Science Association 55(3): 493-514.

Gokhale, B. K. (2006). Political Science. India, Himalaya Publishing House.

Hagopian, F. (2000). Political Development Revisited. U.S, Sage Publication.

Hemant, S. (2003) Communication and nation-building: Comparing US Models of Assililation and Thitd World Modernization.

Hungtington, S. (1968). Political Order in Changing Societis. U.S, Yale University Press.

La Palombara, J. (1963). Bureacracy and Political Development. U.S, Princeton University Press.

Laski, H. (1967). A Grammer of Politics. U.S, HarperCollins Publishers Ltd.

Lenczowski, G. (1972). "United States' Support for Iran's Independence and Integrity, 1945-1959." sage pub-The ANNALS of the American Academy of Political and Social Science 401(1).

Lerner, D. (1958). The Passing of Traditional Society: Modernizing The Middle East. U.S, The Free Press.

Lipset, S. M. (1959). "Some Social Requisites of Democracy: Economics Development and Political Legitimacy." American Political Science Association 53(1): 69-105.

Pye, L. (1964). "Communications and Political Development." The Journal of Politics 26(1): 241-241.

Pye, L. (1965). Political Culture and Political Development. U.S, Prinston University Press.

Pye, L. (1966). Aspects of Political Development. U.S, Little Brown \& Co.

Rustow, D. A. (1970). "Transition to Democracy : Toward a Dynamic Model." Comparative Politics 2(3): 337-363.

Sedehi, A. and S. Tabrizchi (1974). "A Theory of Economic Growth and Political Development: the Case of Iran." International Studies 13(4): 424-440.

Zonis, M. (1968). "Political Elites and Political Cynicism in Iran." Comparative political 
Studies-Sage Publication 1(3): 351-371. 